\title{
PILKADA CALON TUNGGAL DI KABUPATEN PATI TAHUN 2017: SUATU TINJAUAN OLIGARKISME PARPOL
}

\author{
Achmad Ronggo Prihatmono ${ }^{1}$, Kris Nugroho ${ }^{2}$ \\ ${ }^{1}$ Departemen Ilmu Politik, Fakultas Ilmu Sosial dan Ilmu Politik, Universitas Airlangga \\ ronggoronggo170@gmail.com \\ ${ }^{2}$ Departemen Ilmu Politik, Fakultas Ilmu Sosial dan Ilmu Politik, Universitas Airlangga \\ kris.nugroho@fisip.unair.ac.id
}

\begin{abstract}
The phenomenon of a single candidate lately happens a lot in Indonesia, especially in the sphere of local election democratic parties. In the elections held simultaneously in Indonesia in 2017, many regions in the elections were only attended by one candidate pair. This makes the climate of competition in democracy not as expected with democracy. Democracy aims to make elite circulation happen, so that the ruling elite does not dominate so that it becomes an oligarchy. Democracy can turn into an oligarchy if a small group of groups dominates and tries to maintain power in order to remain in the circle of power. We have encountered many oligarchs in political parties, where the DPP of political parties determines the direction of political parties, even in determining the candidates to be carried by political parties in the elections and political lobbying in forming coalitions. The author uses the theory of iron oligarchy Robert Michels as an analytical aid. The research method uses descriptive qualitative research methods in explaining the phenomena that occur. Research data obtained through in-depth interviews with informants. The results show that the phenomenon of a single candidate is not always due to the high electability of a candidate pair, it can also occur because of the dominant oligarchy in political parties at the central level affects to the regional level.
\end{abstract}

Keywords: single candidates, democracy, oligarch.

\section{PENDAHULUAN}

Pergantian kepemimpinan yang terjadi dalam sistem demokrasi dilakukan dengan melalui pemilihan terhadap calon pemimpin. Pemilihan tersebut sebagai wujud dari kedaulatan rakyat berupa hak rakyat untuk memilih calon pemimpin. Sebagai upaya mewujudkan demokrasi pada tingkat lokal, penyelenggaraan pemilihan kepala daerah secara langsung oleh rakyat pertama kali dibuatlah Undangundang No. 32 tahun 2004 tentang pemerintahan daerah bagian kedelapan pemilihan kepala daerah dan wakil kepala daerah. Undang-undang tersebut menyebutkan bahwa Gubernur, Bupati dan Walikota sebagai kepala daerah provinsi, kabupaten dan kota dipilih secara demokratis. Undangundang No. 32 tahun 2004 tentang pemerintahan daerah, menjadi dasar dilaksanakannya pemilihan umum kepala daerah secara langsung oleh rakyat mulai dari tahun 2005 hingga tahun 2013. Pelaksanaan pilkada tersebut dilaksanakan secara terpisah waktunya di setiap daerah karena mekanisme waktu dari pelaksanaan pilkada masih belum ditentukan.

Tahun 2015, dibuat UU No. 8 tahun 2015 tentang pemilihan Gubernur, Bupati dan Walikota, yang mengatur mengenai mekanisme pelaksanaan pilkada yang dilaksanakan secara serentak di seluruh kabupaten, kota dan provinsi di Indonesia. Dalam pelaksanaan dari UU No. 8 tahun 2015 mengalami permasalahan, yaitu dalam pilkada serentak harus terdapat sedikitnya dua pasangan calon kepala daerah dan wakil kepala daerah, sedangkan di beberapa daerah masih terdapat calon tunggal saja. Hal ini mengakibatkan ditundanya pilkada di beberapa daerah di Indonesia dengan harapan akan muncul calon 
lain yang menjadi lawan dalam pilkada. Karena Undang-undang tidak dapat menunda pelaksanaan pilkada dengan tanpa batasan waktu, maka diperbarui dengan UU No. 10 tahun 2016 tentang perubahan kedua pemilihan Gubernur, Bupati dan Walikota, yang memperbolehkan pelaksanaan pilkada dengan satu pasangan calon saja, namun pasangan calon tunggal harus melawan kotak kosong. Artinya rakyat di daerah tersebut mempunyai hak untuk memilih setuju atau tidak calon tunggal tersebut menjadi kepala daerah dan wakil kepala daerah.

Pemilihan umum kepala daerah yang dilakukan secara langsung, sesuai dengan ketentuan UU No. 32 Tahun 2004 pertama kali telah berhasil dilaksanakan pada tahun 2005. Pelaksanaan pilkada langsung diselenggarakan untuk memilih Gubernur, Bupati dan Walikota secara demokratis. Pemilihan kepala daerah secara langsung memiliki kaitan dengan pelaksanaan kedaulatan rakyat yang ada dalam prinsip sebuah negara demokratis. Melalui penyelengaraan pilkada langsung berarti demokrasi pada tingkat lokal telah berhasil mencapai tujuan-tujuan dasarnya, yaitu memilih kepala daerah melalui sebuah mekanisme pemilihan yang demokratis yang bebas, adil dan dengan tanpa kekerasan. Selain itu kepala daerah yang dipilih oleh rakyat melalui pemilihan umum secara langsung, memiliki legitimasi yang kuat karena didukung oleh rakyat yang memberikan suara secara langsung. Penelitian sebelumnya mengenai fenomena calon tunggal pada Pilkada Kabupaten Pati tahun 2017 pernah dilakukan oleh Safira Yuristianti, yang meneliti mengenai sistem rekrutmen calon oleh partai politik. Dalam penelitian tersebut, membahas tentang bagaimana sistem rekrutmen yang dijalankan oleh masing-masing partai politik dan sisi prgamatisme partai politik dalam mengusung calon. Partai politik mengorbankan ideologi partai dengan menjalin koalisi dengan partai politik yang bahkan ideologinya berseberangan antar partai, akhirnya muncul fenomena calon tunggal dalam pilkada Kabupaten Pati tahun 2017. Alusia Prita Parahita, meneliti kemenangan kotak kosong dalam pemilihan Bupati dan Wakil Bupati Kabupaten Pati tahun 2017, membahas tentang kemenangan kotak kosong mengalahkan pasangan calon tunggal Haryanto-Saiful. Penelitian ini memiliki kelemahan karena yang menang adalah pasangan calon tunggal Haryanto-Saiful, kotak kosong hanya menang di beberapa desa saja. Siti Dwi Puspitasari, meneliti tentang peran AKDPP dalam kemenangan kotak kosong di Desa Gajahmati dan Desa Maitan pada pilkada Kabupaten Pati tahun 2017. Penelitian ini memiliki kelemahan yaitu lebih pro terhadap AKDPP dan tidak menyoroti bahwa di balik AKDPP juga terdapat kepentingan elit politik dan tidak murni dari rakyat.

Penelitian ini membahas mengenai oligarkisme partai politik dalam fenomena calon tunggal pilkada Kabupaten Pati tahun 2017. Penelitian ini perlu untuk dilakukan karena masih belum banyak penelitian yang meneliti bagaimana oligarkisme partai dalam menyebabkan munculnya calon tunggal pada pilkada Kabupaten Pati tahun 2017. Terjadinya calon tunggal pada Pilkada Kabupaten Pati tahun 2017 dapat terjadi karena sifat oligarkisme partai yang mengikuti kehendak dari pimpinan partai. Bahkan dalam ranah pilkada, DPP partai memegang kuasa untuk memberikan surat rekomendasi terhadap siapa calon yang akan diusung oleh partai dan dalam membentuk koalisi dengan partai politik lain dengan tujuan memenangkan pasangan calon yang diusung, disertai dengan lobi politik dan politik 
transaksional antar partai. Selain tujuan untuk tetap berada di lingkaran kekuasaan, partai politik juga mendapatkan keuntungan finansial dari pasangan calon yang diusung. Pasangan calon Haryanto-Saiful menjadi calon tunggal dengan mendapatkan dukungan dari koalisi delapan partai politik. Selain sebagai petahana, kekuatan modal yang dimiliki oleh pasangan Haryanto-Saiful menjadi daya tarik bagi partai politik agar mau menjadi kendaraan politik bagi pasangan calon tunggal Haryanto-Saiful.

\section{Fenomena Calon Tunggal dalam Pilkada Kabupaten Pati Tahun 2017}

Proses terjadinya fenomena calon tunggal dapat dibagi menjadi dua pola. Pertama, selama masa pendaftaran calon kepala daerah dan wakil kepala daerah hanya ada satu pasangan calon saja yang mendaftar di KPUD sampai berakhirnya proses seleksi dan pengumuman. Kedua, sebenarnya sudah ada lebih dari satu calon yang mendaftar sebagai calon kepala daerah di KPUD namun yang lolos dalam proses seleksi dan berhak untuk mengikuti proses pilkada hanya satu pasangan calon saja. Pada kasus pola yang pertama yaitu, calon pasangan tersebut kebanyakan merupakan petahana yang memiliki elektabilitas yang tinggi sehingga, mendominasi dalam pilkada yang menyebabkan mundurnya caloncalon potensial untuk mendaftarkan diri dalam pilkada. Sedangkan untuk pola yang kedua terjadi karena pasangan calon yang lain mengundurkan diri pada saat berlangsungnya proses seleksi atau mereka tidak melengkapi syarat-syarat sebagai calon dalam pilkada sehingga gugur dalam proses seleksi.

Fenomena yang menarik dari diselenggarakannya pemilihan kepala daerah secara langsung adalah munculnya kapitalisasi dalam proses pemilihan kepala daerah berupa money politics dan politik transaksional (Amirudin \& Bisri, 2006). Munculnya kapitalisasi dalam pemilihan kepala daerah menjadi penyebab dari mahalnya biaya yang dibutuhkan oleh calon kepala daerah, dari model pemilihan yang sebelumnya dipilih oleh DPRD atas persetujuan dari pemerintah pusat. Hal ini dapat menjadi celah untuk dimanfaatkan oleh para elit politik yang tidak hanya berkompetisi untuk mengejar kekuasaan semata namun, sekaligus juga mendapatkan keuntungan ekonomi dari pesta demokrasi lokal pemilihan kepala daerah.

Fenomena yang terjadi pada pilkada langsung Kabupaten Pati tahun 2017 hanya ada calon tunggal yang juga merupakan petahana, yaitu pasangan calon Haryanto dan Saiful Arifin yang maju mencalonkan diri sebagai calon bupati dan wakil bupati. Tidak ada yang menjadi lawan dari pasangan calon HaryantoSaiful sehingga, pasangan calon Haryanto-Saiful melawan kotak kosong dalam pilkada Kabupaten Pati tahun 2017. Sebelumnya belum ada fenomena calon tunggal pada Pilkada yang dilangsungkan di Kabupaten Pati, baru pada pilkada pada tahun 2017 pertama kali terjadi fenomena calon tunggal pada pilkada yang dilaksanakan di Kabupaten Pati.

Berdasarkan pada fenomena yang terjadi dalam pilkada Kabupaten Pati tahun 2017, menunjukkan bahwa dalam pilkada tersebut masih belum dapat untuk dikatakan sebagai pilkada yang aspiratif dan demokratis, karena pilkada Kabupaten Pati tahun 2017 masih belum kompetitif, artinya dalam pilkada tersebut Haryanto sebagai petahana tidak mempunyai lawan yang menjadi kompetitornya 
dalam Pilkada Pati 2017, dan menjadi satu-satunya calon yang mencalonkan diri sebagai pasangan calon Bupati dan wakil Bupati Kabupaten Pati. Dari adanya fenomena calon tunggal ini mempunyai implikasi terhadap demokrasi yang ada di Indonesia, karena yang diharapkan dengan adanya demokrasi akan ada sirkulasi elit, sedangakan dalam demokrasi yang masih dikuasai oleh oligarki menyebabkan sirkuasi elit yang ada tidak berjalan dengan baik. Dapat dikatakan terjadi sirkuasi dalam elit, namun yang menjadi permasalahan adalah perputaran elit yang ada hanya berotasi dalam lingkup lingkaran oligarki elit tersebut. Melalui cara ini, oligarki mempertahankan dominasi politik dengan menutup jalan bagi pesaing politik yang dapat melengserkan mereka dari kekuasaan politik. Kalangan oligarki lebih banyak memanfaatkan sumberdaya material untuk melancarkan usaha politik mereka. Dengan memanfaatkan situasi ketimpangan materi yang ada dalam lingkungan masyarakat, menjadi cara untuk memenangkan kontestasi politik. Apalagi jika kekuasaan material yang dimiliki oleh kaum oligarki juga didukung oleh mahalnya biaya politik dan tradisi budaya pilitik uang yang ada di masyarakat, semakin mudah untuk menggeser pesaing politik yang kurang memiliki sumber daya materi yang kuat.

Fenomena calon tunggal di Kabupaten Pati menarik untuk diteliti karena, calon tunggal diusung oleh tujuh partai politik yang memiliki kursi di DPRD Kabupaten Pati. Di Kabupaten Pati terdapat 17 partai politik yaitu: PDIP, Gerindra, PKB, Demokrat, Golkar, PKS, Hanura, Nasdem, PPP, PAN, PBB, PKPI, Partai Berkarya, Partai Idaman, PSI, Perindo, dan Partai Garuda (Kesbangpol Jateng, n.d.). DPRD Kabupaten Pati terdapat 50 orang wakil rakyat, partai politik yang mendapatkan kursi di DPRD Kabupaten Pati diantaranya yaitu: PDIP 8 kursi, Gerindra 9 kursi, PKB 7 kursi, Demokrat 8 kursi, Nasdem 4 kursi, PKS 5 kursi, Golkar 5 kursi, Hanura 4 kursi (DPRD Kabupaten Pati, 2019). Pasangan calon tunggal Haryanto-Saiful diusung oleh 8 partai politik yaitu: PDIP, PKB, Gerindra, Demokrat, Hanura, Golkar, PKS, PPP. Partai politik yang memiliki kursi di DPRD namun tidak mendukung calon tunggal yaitu hanya partai Nasdem saja, sedangkan partai PPP tidak mendapatkan kursi di DPRD namun ikut dalam koalisi partai politik yang mengusung pasangan calon Haryanto-Saiful.

\section{Haryanto Melawan Kotak Kosong}

Sebelum berlangsungnya pilkada Pati, banyak laporan mengenai maraknya dugaan politik uang yang dilakukan oleh pasangan calon tunggal dan menyebabkan panasnya situasi yang terjadi antara pendukung dari Haryanto dengan relawan yang mendukung kotak kosong. Bahkan ada gerakan masyarakat yang tidak menginginkan Haryanto untuk memimpin kembali Kabupaten Pati. Gerakan masyarakat ini tidak hanya melaporkan adanya kecurangan money politics yang dilakukan oleh pasangan calon tunggal kepada Panwaslu saja melainkan juga mengajukan gugatan terkait kecurangan pada pilkada Pati kepada Mahkamah Konstitusi (Tribunnnews, 2017).

Selain karena calon tunggal diusung oleh tujuh partai politik, fenomena calon tunggal di Kabupaten Pati juga menarik untuk diteliti karena rendahnya tingkat partisipasi pemilih. Hasil rekapitulasi pilkada Pati pasangan calon Haryanto-Saiful mendapatkan 519.675 suara, dari total 697.437 suara sah. Sementara kotak kosong mendapatkan suara sebanyak 177.762 suara. Namun, jika dihitung 
dari jumlah daftar pemilih tetap Pati yang mencapai 1.034.256, tingkat partisipasi pemilih yang ada hanya $68,9 \%$ (Tribunnews, 2017).

Tabel 1. Hasil Perolehan Suara Pilkada Kabupaten Pati Tahun 2017.

\begin{tabular}{|c|c|c|c|c|c|}
\hline $\begin{array}{c}\text { Nama Pasangan } \\
\text { Calon }\end{array}$ & $\begin{array}{l}\text { Rincian Jumlah } \\
\text { Perolehan Suara } \\
\text { Pasangan Calon }\end{array}$ & $\begin{array}{c}\text { H. Haryanto, SH, } \\
\text { MM, M.Si } \\
\text { Dan } \\
\text { H. Saiful Arifin }\end{array}$ & Kolom Kosong & $\begin{array}{c}\text { Jumlah Suara } \\
\text { Sah Calon }\end{array}$ & $\begin{array}{l}\text { Jumlah } \\
\text { Suara Tidak } \\
\quad \text { Sah }\end{array}$ \\
\hline \multirow[t]{22}{*}{ Kecamatan } & Batangan & 24449 & 1846 & 26295 & 455 \\
\hline & Cluwak & 24016 & 2554 & 26570 & 411 \\
\hline & Dukuhseti & 26321 & 5933 & 32254 & 502 \\
\hline & Gabus & 23503 & 8692 & 32195 & 714 \\
\hline & Gembong & 20326 & 5238 & 25564 & 515 \\
\hline & Gunungwungkal & $\underline{16189}$ & $\underline{4462}$ & $\underline{20651}$ & $\underline{421}$ \\
\hline & Jaken & 25029 & 1510 & 26539 & 420 \\
\hline & Jakenan & 19916 & 4746 & 24662 & 488 \\
\hline & Juwana & 39919 & 13471 & 53390 & 1031 \\
\hline & Kayen & 24157 & 11414 & 35571 & 1050 \\
\hline & Margorejo & 23308 & 9964 & 33272 & 775 \\
\hline & Margoyoso & 22639 & 16340 & 38979 & 908 \\
\hline & Pati & 35067 & 23818 & 58885 & 1265 \\
\hline & Pucakwangi & 23939 & 2894 & 26833 & 534 \\
\hline & Sukolilo & 34121 & 9036 & 43157 & 1032 \\
\hline & $\underline{\text { Tambakromo }}$ & $\underline{15358}$ & $\underline{121918}$ & $\underline{25518}$ & $\underline{1011}$ \\
\hline & Tayu & 25861 & 10160 & 36525 & 770 \\
\hline & $\underline{\text { Tlogowungu }}$ & 23775 & $\underline{10664}$ & $\underline{30198}$ & $\underline{604}$ \\
\hline & Trangkil & 21709 & 6423 & 34103 & 706 \\
\hline & $\underline{\text { Wedarijaksa }}$ & $\underline{22785}$ & $\underline{12394}$ & $\underline{34492}$ & $\underline{773}$ \\
\hline & Winong & 27288 & 4559 & 31847 & 599 \\
\hline & Jumlah Akhir & 519675 & 177762 & 697437 & 14984 \\
\hline
\end{tabular}

Sumber: Arsip Data KPU Kabupaten Pati.

Pilkada Kabupaten Pati tahun 2017 hanya diikuti oleh satu pasangan calon. Pasangan calon tunggal Haryanto-Saiful berhasil memenangkan pilkada Kabupaten Pati tahun 2017, dengan mendapatkan suara sebanyak 519.675 suara, sedangkan kotak kosong hanya meraih 177.762 suara. Dengan hasil ini, Haryanto kembali terpilih sebagai Bupati Kabupaten Pati untuk periode ke-2, dengan masa jabatan tahun 2017 hingga tahun 2022.

Fenomena calon tunggal pada pilkada Kabupaten Pati tahun 2017 menjadi fenomena yang menarik, karena tingkat partisipasi pemilih dari masyarakat Kabupaten Pati, yang tidak menggunakan hak pilihnya dalam pilkada Kabupaten Pati tahun 2017 cukup besar. Berikut ini tabel tingkat partisipasi pemilih masyarakat Kabupaten Pati, dalam pilkada Kabupaten Pati tahun 2017 berdasarkan jumlah pemilih yang terdaftar dalam DPT. 
Tabel 2. Tingkat partisipasi pemilih masyarakat Kabupaten Pati dalam pilkada Kabupaten Pati tahun 2017.

\begin{tabular}{llrrc}
\hline No & Kecamatan & $\begin{array}{c}\text { Jumlah Pengguna } \\
\text { Hak Pilih }\end{array}$ & $\begin{array}{c}\text { Jumlah Pemilih } \\
\text { Terdaftar dalam DPT }\end{array}$ & $\begin{array}{c}\text { Persentase Tingkat } \\
\text { Partisipasi Pemilih }\end{array}$ \\
\hline 1 & Batangan & 26750 & 33998 & $78,68 \%$ \\
\hline 2 & Cluwak & 26981 & 38161 & $70,70 \%$ \\
\hline 3 & Dukuhseti & 32756 & 47481 & $68,98 \%$ \\
\hline 4 & Gabus & 32909 & 51134 & $64,35 \%$ \\
\hline 5 & Gembong & 26079 & 37222 & $70,06 \%$ \\
\hline 6 & Gunungwungkal & 21072 & $69,56 \%$ \\
\hline 7 & Jaken & 26959 & 30293 & $71,36 \%$ \\
\hline 8 & Jakenan & 25150 & 37778 & $63,83 \%$ \\
\hline 9 & Juwana & 54421 & 39398 & $76,55 \%$ \\
\hline 10 & Kayen & 36621 & 71085 & $58,22 \%$ \\
\hline 11 & Margorejo & 34047 & 62892 & $73,45 \%$ \\
\hline 12 & Margoyoso & 39887 & 46350 & $69,86 \%$ \\
\hline 13 & Pati & 60150 & 57089 & $71,75 \%$ \\
\hline 14 & Pucakwangi & 27367 & 83823 & $69,01 \%$ \\
\hline 15 & Sukolilo & 44189 & 39652 & $62,90 \%$ \\
\hline 16 & Tambakromo & 26529 & 70248 & $59,02 \%$ \\
\hline 17 & Tayu & 37295 & 44949 & $68,32 \%$ \\
\hline 18 & Tlogowungu & 30802 & $545,64 \%$ \\
\hline 19 & Trangkil & 34809 & 425037850 & $72,47 \%$ \\
\hline 20 & Wedarijaksa & 35202 & 48058 & $72,43 \%$ \\
\hline 21 & Winong & 32446 & 48660 & $73,24 \%$ \\
\hline & & 712421 & 52101 & $62,27 \%$ \\
\hline & & & 5456 & 6 \\
\hline
\end{tabular}

Dari banyaknya perlawanan yang dilakukan oleh masyarakat yang menginginkan sosok pemimpin yang baru, seperti yang dilakukan oleh masyarakat Kabupaten Pati seperti ini, sebetulnya sudah mencerminkan adanya demokrasi dalam pilkada yang diselenggarakan di Kabupaten Pati namun, kebenaran dari hal ini masih menjadi sebuah pertanyaan dan menjadi penelitian saya. Apakah benar masyarakat melakukan itu semua karena kehendak dari masyarakat, untuk melawan kecurangan yang ada, ataukahhanya merupakan settingan yang memang disusun dengan rapi oleh pihak tim sukses dari Haryanto, untuk menciptakan kondisi seolah-olah dalam Pilkada Pati demokrasi memang benarbenar hidup. Meskipun hanya diikuti oleh satu pasangan calon saja tanpa adanya lawan yang menjadi penantang daripada Haryanto, selaku petahana dan didukung oleh hampir semua partai politik besar yang ada di Kabupaten Pati.

Meskipun demikian, tidak seharusnya hanya ada calon tunggal saja yang maju dalam pilkada. Dalam demokrasi yang hidup, seharusnya partai-partai politik lain mempunyai kader dari partai politik masing-masing, yang dapat diusung sebagai calon kepala daerah dari partai politik mereka. Namun situasi yang terjadi malah sebaliknya, tidak ada partai politik yang mencalonkan kader dari partai untuk menjadi penantang dari calon tunggal, bahkan partai-partai tersebut berkoalisi untuk memenangkan sang petahana. Jika dihitung-hitung dengan bergabungnya banyak partai besar dalam koalisi untuk memenangkan calon tunggal, secara otomatis seharusnya dapat dengan mudah untuk mengalahkan kotak kosong, sebab secara kuantitas semakin banyaknya partai politik yang mendukung maka semakin 
besar pula suara yang dapat diperoleh oleh calon tersebut. Hal ini justru mematikan demokrasi lokal yang ada sehingga, demokrasi lokal yang ada tidak mengenal adanya kompetisi yang sengit dalam demokrasi yang bertujuan untuk memilih calon pemimpin terpilih yang memang dicintai oleh masyarakatnya.

Tingkat partisipasi masyarakat Kabupaten Pati dalam menggunakan hak pilihnya, dalam pilkada Kabupaten Pati tahun 2017 cukup rendah, yaitu hanya 712.421 orang dari jumlah 1.037.850 orang atau 68,64\% dari jumlah DPT. Fenomena calon tunggal di dalam Pilkada Kabupaten Pati tahun 2017 menjadi menarik, karena tingkat partisipasi masyarakat Kabupaten Pati yang cukup rendah. Rendahnya tingkat partisipasi masyarakat Pati dalam menggunakan hak suaranya ini berkaitan dengan kasus Haryanto yang mengizinkan beroperasinya pabrik semen di wilayah bukit Kendeng. Masyarakat Pati menilai Haryanto lebih pro terhadap investor untuk mendapatkan keuntungan ekonomi, daripada kepentingan masyarakat yang terdampak akibat beroperasinya pabrik semen.

\section{Fenomena Calon Tunggal dalam Teori Hukum Besi Oligarki}

Teori yang tepat untuk membahas mengenai fenomena calon tunggal pada pilkada Kabupaten Pati, yaitu menggunakan teori hukum besi oligarki yang dicetuskan oleh Robert Michels. Selain menggunakan teori hukum besi oligarki, untuk membahas mengenai fenomena calon tunggal di Kabupaten Pati, juga memerlukan tambahan dari adanya lobi-lobi politik dan politik transaksional yang dilakukan oleh elit politik untuk memenangkan pasangan calon tunggal. Hal ini dapat dilihat dari tujuh partai politik yang memiliki kursi di DPRD Kabupaten Pati yaitu PDIP, Gerindra, PKB, Demokrat, PKS, Golkar, dan Hanura semuanya membentuk koalisi mengusung pasangan calon tunggal HaryantoSaiful.

Asal-usul teori oligarki pada awalnya berasal dari teori elit dan kekuasaan dalam ilmu politik. Kata elit berasal dari bahasa latin yaitu eligere yang memiliki arti memilih yang dalam pengertian yang lebih luas yaitu sekelompok orang yang mempunyai kedudukan yang tinggi dalam suatu masyarakat (Keller, 1995). Kelompok Elit yaitu kelompok yang mempunyai kekuasaan dan dapat mengendalikan orang banyak jumlahnya sedikit. Teori elit ini kemudian dicetuskan oleh Pareto bahwa elit berada pada lapisan atas masyarakat dan terbagi menjadi dua bagian yaitu: elit yang memerintah dan elit yang tidak memerintah. Sedangkan masyarakat berada pada lapisan bawah dan berjumlah banyak atau disebut juga dengan non elit (Alfian, 2009).

Teori hukum besi oligarki merupakan kelanjutan dari teori elit, yang mana elit merupakan sekelompok kecil orang yang memiliki sumberdaya baik kekuasaan, maupun finansial yang melebihi banyak orang, sehingga timbul dominasi dari elit terhadap orang banyak. Dampaknya ialah distribusi kekuasaan di masyarakat tidak tersebar dengan rata, melainkan hanya dipegang oleh orang atau sekelompok orang yaitu elit, selanjutnya kalangan internal elit memiliki sifat yang sama, menyatu dan mempunyai kesadaran sebagai elit dan mengatur keberlangsungan kelompok mereka sebagai elit, sehingga kelompok elit merupakan kelompok yang otonom (Mas'oed \& MacAndrew, 2006). Lebih jauh saya akan berfokus tentang teori hukum besi oligarki dari Robert Michels dan kaitannya dalam 
partai politik. Dimulai pada tahun 1911 Robert Michels menulis bukunya yang berjudul Zur Soziologie des Parteiwesens in der modernen Demokratie: Untersuchungen Uber die oligarchischen Tendenzen des Gruppenlebens membuat teori hukum besi oligarki (Lipset \& Sanit, 1984). Dalam bukunya tersebut Robert Michels mengatakan bahwa semua partai politik mempunyai kekuasaan yang sifatnya oligarkis yang berlandaskan dengan demokrasi. Sifat oligarkis dalam partai politik disebabkan oleh kebutuhan akan kepemimpinan dalam partai politik (New World Encyclopedia, n.d.).

Teori hukum besi oligarki dapat digunakan untuk melihat bagaimana keputusan dari DPP suatu partai politik memengaruhi terhadap calon yang akan diusung oleh partai politik tersebut, meskipun partai politik masih memiliki kader lain yang berkualitas. Hal ini seperti yang dialami oleh Budiono, mantan wakil bupati Kabupaten Pati yang telah mendaftarkan diri ke PDIP sebagai calon Bupati dalam pilkada Pati tahun 2017. Budiono ingin menggabungkan kekuatan PDIP dengan PKB karena Budiono merupakan seorang tokoh NU. Keinginan Budiono tidak terpenuhi karena DPP PDIP memutuskan untuk mengusung pasangan Haryanto-Saiful sebagai calon yang diusung oleh PDIP. Demikian juga yang terjadi pada PKB, PKB juga masuk kedalam koalisi partai politik yang mengusung pasangan calon tunggal Haryanto-Saiful. Partai politik tidak hanya mencari kader yang berkualitas saja, partai politik juga mempertimbangkan popularitas dan kekuatan modal yang dimiliki oleh seorang calon, sebelum diusung oleh partai politik.

Selain menggunakan teori hukum besi oligarki, untuk mengamati fenomena calon tunggal memerlukan tambahan dari sudut pandang loby politik dan politik transaksional. Seperti yang terjadi pada fenomena calon tunggal pilkada Pati 2017, tujuh partai politik yang mendapatkan kursi di DPRD mengusung pasangan Haryanto-Saiful. Dibalik terbentuknya koalisi partai politik tersebut, tentunya ada loby politik dan politik transaksional yang dilakukan oleh elit dari partai politik untuk memenangkan pasangan calon tunggal Haryanto-Saiful.

Fenomena calon tunggal pada pilkada Kabupaten Pati tahun 2017 menggunakan hukum besi oligarki karena, keputusan terhadap siapa calon yang akan diusung oleh partai politik ditentukan oleh keputusan surat rekomendasi dari DPP Partai. Hal ini sesuai dengan asumsi dari teori hukum besi oligarkhi dari Robert Michels yang menyebutkan bahwa organisasi sedemokratis apapun pasti akan terdapat oligarki, termasuk dalam organisasi yang besar seperti partai politik. Oligarki muncul karena dalam sebuah organisasi memerlukan adanya kepemimpinan. Kepemimpinan dipegang oleh sekelompok orang timbul menjadi oligarkhi, karena adanya upaya untuk mempertahankan kekuasaan atau tetap berada di lingkaran kekuasaan. Dalam kasus fenomena calon tunggal pada pilkada Kabupaten Pati tahun 2017, berkaitan dengan kekuasaan oligarki yang dipegang oleh DPP Partai. Tujuh partai politik yang memiliki kursi di DPRD Kabupaten Pati, bersama membentuk koalisi memenangkan pasangan calon tunggal Haryanto-Saiful.

Oligarki yang ada dalam DPP partai politik sulit untuk diganggu-gugat. Seperti yang pernah terjadi pada pilkada Kabupaten Pati tahun 2012. Pilkada Kabupaten Pati tahun 2012 diulang dua kali karena Sunarwi yang pada saat itu menjabat sebagai ketua DPC PDIP Kabupaten Pati, tidak 
mengindahkan rekomendasi dari DPP PDIP dengan mendaftarkan dirinya sebagai calon Bupati Kabupaten Pati tahun 2012 yang diusung oleh PDIP. Hal ini berdampak dengan Sunarwi diberhentikan dari jabatannya sebagai ketua DPC PDIP Kabupaten Pati, serta dikeluarkan dari PDIP. Tindakan Sunarwi ini telah menentang keputusan DPP PDIP yang merekomendasikan untuk mengusung Imam Suroso sebagai calon Bupati yang diusung oleh PDIP.

Hal ini sesuai dengan asumsi dari teori hukum besi oligarkhi Robert Michels, yang menyebutkan adanya kecenderungan dominasi oleh sekelompok kecil orang. Menurut Michels, oligarki muncul dalam empat dimensi politik, yaitu dari segi organisasi, oligarkhi dalam kepemimpinan, oligarki dalam konteks hubungan organisasi dengan rakyat dan oligarkhi dalam kekuasaan pemerintahan (Varma, 2003). Partai politik mempunyai kekuatan oligarkis, kekuatan oligarkis tersebut akan terjadi juga dalam pemerintahan, hal ini tidak memerdulikan bagaimana partai politik mendapatkan kekuasaan, baik melalui pemilihan umum yang demokratis atau dengan cara penggulingan kekuasaan atau revolusi. Perbedaan antara oligarki dengan demokrasi ialah pada kepentingan yang ingin dicapai, dalam oligarki kepentingan yang ingin dicapai adalah kepentingan dari kelompok para pemegang kekuasaan, sementara dalam demokrasi, kepentingan yang ingin dicapai ialah kepentingan dari orang banyak, meskipun bukan konstituen yang dia wakili atau yang memilih dia sebagai wakil.

Dalam pemerintahan yang demokratis, walaupun kekuasaan dipegang oleh sedikit orang, namun tujuan yang ingin dicapai adalah kepentingan bersama. Hal inilah yang membedakan dengan oligarki, yang bertujuan untuk mendapatkan kepentingan sekelompok kecil orang yang berkuasa. Yang menjadi hal positif yang diperoleh dengan hidupnya demokrasi adalah fungsi partai politik sebagai tempat untuk menghimpun aspirasi dari rakyat, yang ditujukan kepada pemerintah menjadi tercapai (Budiarjo, 2003). Alasan yang kuat supaya partai politik berjalan sesuai fungsinya ialah asal mula terbentuknya partai politik disebabkan, karena demokrasi menuntut kekuatan rakyat dapat menentukan kebijakan yang akan dibuat oleh negara secara langsung, agar sesuai dengan pilihan dari rakyat melalui perantara partai politik. Melalui ungkapan ini berarti rakyat merupakan golongan mayoritas orang yang menginginkan dipimpin oleh sekelompok kecil orang melalui sistem demokrasi. Faktor yang menyebabkan hidupnya oligarki yaitu sebuah organisasi ataupun partai politik memiliki kebutuhan taktis maupun kebutuhan teknis yang harus dipenuhi oleh organisasi atau partai. Kebutuhan-kebutuhan ini mengharuskan partai politik dapat memenuhi kebutuhan tersebut, sehingga partai politik terperangkap dalam hukum besi oligarki. Selanjutnya adalah, apabila partai politik sudah terperangkap kedalam hukum besi oligarki maka, partai politik tidak lagi mematuhi terhadap konstituennya, tetapi partai politik akan patuh terhadap elit yang menguasai partai politik sehingga, partai politik menjadi alat bagi golongan oligarkis partai dalam mempertahankan kekuasaan dan mencapai kepentingannya dan tidak lagi memperhatikan aspirasi rakyat.

Jika merujuk pada teori hukum besi oligarki dari Robert Michels yang menyatakan bahwa organisasi melahirkan dominasi oleh golongan terpilih atas pemilih, oleh pemegang mandat atas pemberi mandat, oleh utusan atas yang mengutus, barang siapa yang berbicara tentang organisasi ia 
juga berbicara tentang oligarki. Melihat pada fenomena oligarki saat ini, maka dapat dijumpai tidak hanya pada partai politik saja namun dalam skala yang lebih luas, oligarki dapat dijumpai dalam pemerintahan, militer, partai politik dan juga birokrasi yang mana kesemuanya memiliki struktur yang hierarkis atau terdapat elit yang memiliki kekuasaan yang mendominasi didalamnya.

\section{Pro dan Kontra Mastarakat Pati terhadap Haryanto}

Pasangan calon tunggal Haryanto-Saiful menjadi satu-satunya pasangan calon yang maju dalam pilkada Kabupaten Pati tahun 2017. Haryanto menuai pro dan kontra sebagai petahana, pasalnya pada periode pertama pemerintahan Haryanto sebagai Bupati Kabupaten Pati, Haryanto membuat kebijakan yang membuat sebagian masyarakat Pati menjadi tidak suka dengan Haryanto. Kebijakan tersebut ialah pemberian izin terhadap beroperasinya pabrik semen di wilayah Bukit Kendeng. Pemberian izin beroperasinya pabrik semen ini memberi dampak yang besar bagi masyarakat Pati, terutama masyarakat yang tinggal di sekitar wilayah Bukit Kendeng. Masyarakat banyak yang kehilangan tempat tinggal dan kerusakan lingkungan yang ditimbulkan akibat beroperasinya pabrik semen.

Isu pabrik semen ini kemudian menjadi senjata bagi lawan politik Haryanto yaitu Budiono yang memiliki keinginan untuk maju dalam pilkada Kabupaten Pati tahun 2017. Budiono tidak dapat mencalonkan diri karena tidak memenuhi persyaratan ambang batas minimum untuk mencalonkan diri. Kemudian muncul gerakan AKDPP yang merupakan boneka dari Budiono dengan misi memenangkan kotak kosong, akan tetapi masyarakat Pati banyak yang memilih untuk tidak memberikan hak suara mereka ke TPS. Hal ini menyebabkan rendahnya tingkat partisipasi masyarakat Pati dalam penyelenggaraan Pilkada Kabupaten Pati tahun 2017.

Sementara masyarakat yang pro terhadap Haryanto sebagai calon tunggal, disebabkan karena Haryanto merupakan putra daerah Pati. Haryanto sejak kecil merupakan warga Kecamatan Batangan, Kabupaten Pati. Hal ini menyebabkan sebagian masyarakat Pati tetap memilih Haryanto dan Haryanto memiliki lumbung suara di Dapil 3. Selain itu, sosok Haryanto juga dikenal oleh masyarakat Pati sebagai pemimpin yang peduloi terhadap rakyat kecil. Haryanto banyak memberikan santunan kepada rakyat kecil, salah satunya yaitu santunan kematian sebesar satu juta rupiah kepada setiap keluarga.

\section{SIMPULAN}

Haryanto menjadi sosok yang dapat menarik banyak partai politik untuk mengusung dia dalam pilkada Kabupaten Pati tahun 2017. Partai-partai politik tersebut menjadi kendaraan politik bagi Haryanto dalam memenangkan pilkada Kabupaten Pati tahun 2017. Partai koalisi pendukung HaryantoSaiful merupakan hampir seluruh partai politik yang memiliki kursi di DPRD Kabupaten Pati. Adanya koalisi gemuk dari partai politik pengusung Haryanto-Saiful menutup kemungkinan adanya calon lain yang muncul sebab kurangnya persyaratan yang dibutuhkan untuk mengusung calon dalam Pilkada. Persyaratan yang dibutuhkan dalam mengusung calon kepala daerah yaitu berdasarkan UU No. 10 Tahun 2016 Pasal 40 ayat (1) yaitu: partai politik atau gabungan partai politik dapat mendaftarkan pasangan calon jika telah memenuhi persyaratan perolehan paling sedikit 20\% dari jumlah kursi Dewan 
Perwakilan Rakyat Daerah atau 25\% dari akumulasi perolehan suara sah dalam pemilihan umum anggota Dewan Perwakilan Rakyat Daerah di daerah yang bersangkutan. Dari persyaratan ini, jika melihat koalisi partai politik yang mengusung Haryanto-Saiful dalam pilkada Kabupaten Pati tahun 2017 merupakan hal yang tidak mungkin memunculkan calon lain, karena hampir semua partai politik yang memiliki kursi di DPRD Kabupaten Pati memilih untuk mengusung Haryanto-Saiful.

Koalisi delapan partai politik mengusung Haryanto-Saiful sebab Haryanto adalah seorang incumbent yang dianggap masih memiliki elektabilitas yang cukup tinggi di Pati. Selain karena faktor Haryanto merupakan seorang incumbent, Haryanto juga merupakan putra daerah Kecamatan Batangan sehingga warga Pati kemungkinan besar akan memilih Haryanto daripada kotak kosong. Faktor yang lain yang menjadikan partai-partai pendukung Haryanto mau menjadi kendaraan politik bagi Haryanto yaitu karena Haryanto mempunyai kekuatan finansial yang kuat juga partai-partai politik pendukung Haryanto menginginkan berada dalam pusaran kekuasaan apabila Haryanto-Saiful terpilih sebagai Bupati Kabupaten Pati tahun 2017-2022.

Membahas mengenai koalisi gemuk dari delapan partai pendukung Haryanto-Saiful, merupakan sebuah bentuk oligarki dari elit politik. Dengan terbentuknya koalisi gemuk tersebut, dan isinya adalah hampir semua partai politik yang mempunyai kursi di DPRD Kabupaten Pati, hal ini menyebabkan tertutupnya kemungkinan adanya calon lain untuk ikut maju dalam Pilkada. Timbulnya fenomena calon tunggal merupakan hasil dari adanya koalisi gemuk ini. Dari koalisi gemuk partai politik pengusung HaryantoSaiful, terlihat bahwa partai-partai tersebut ingin tetap berada dalam pusaran kekuasaan apabila Haryanto-Saiful terpilih menjadi bupati Kabupaten Pati tahun 2017-2022. Hal ini seperti yang dikemukakan oleh Robert Michels mengenai hukum besi oligarki, dimana terjadi dominasi dari segolongan kecil orang terhadap orang banyak Segolongan kecil yang mendominasi disini adalah elitelit dari koalisi partai politik pengusung Haryanto-Saiful terhadap orang banyak yaitu warga Pati. Elitelit dari koalisi partai politik pengusung Haryanto-Saiful menjalin koalisi gemuk sehingga tidak memungkinkan adanya calon lain yang muncul lewat jalur partai politik. Ketidak mungkinan munculnya calon lain dari jalur partai politik terjadi sepertihalnya partai Nasdem yang tidak dapat mengusung Budiono dalam pilkada Kabupaten Pati 2017, karena kurangnya persayaratan jumlah kursi yang dibutuhkan untuk dapat mengusung calon. Hal ini juga membatasi pilihan dari warga Pati untuk memilih pemimpin, karena hanya ada calon tunggal dalam Pilkada Pati tahun 2017. Teori hukum besi oligarki yang dicetuskan oleh Robert Michels menyebutkan bahwa semua organisasi termasuk organisasi yang besar dan kompleks seperti partai politik, mempunyai kekuasaan yang bersifat oligarkis meskipun partai yang berideologikan demokratis sekalipun. Kekuasaan yang bersifat oligarkis ini menyebabkan kekuatan politik yang ada di pemerintahan berada di tangan sekelompok kecil orang dan mempunyai dampak yang besar bagi banyak orang.

Koalisi partai politik pengusung Haryanto-Saiful mau menjadi kendaraan politik bagi Haryanto-Saiful dengan tujuan agar mereka tetap berada dalam lingkup pusaran kekuasaan dalam pemerintahan Haryanto.Kekuatan oligarkis yang terbentuk dari elit yang mendukung Haryanto-Saiful 
dapat membunuh pada demokrasi. Seperti halnya dalam pilkada Pati tahun 2017, dimana hanya terdapat calon tunggal saja yang mencalonkan diri dalam pilkada Pati tahun 2017 berakibat membatasi pilihan dari warga Pati, karena tidak ada pilihan lain kecuali calon tunggal atau kotak kosong. Disisi lain pasangan calon tunggal Haryanto-Saiful mendapatkan keuntungan politik dari adanya kekuatan oligarki dari elitelit partai politik yang mengusung dirinya, keuntungan yang didapat oleh Haryanto selaku calon tunggal yaitu tidak ada pesaing bagi dirinya dalam pilkada Kabupaten Pati tahun 2017.

\section{DAFTAR PUSTAKA}

Alfian MA (2009) Menjadi Pemimpin Politik. Jakarta: Gramedia Pustaka Utama.

Amirudin \& Bisri AZ (2006) Pilkada Langsung: Problem dan Prospek. Yogyakarta: Pustaka Pelajar.

Arsip data KPU Kabupaten Pati.

Budiardjo M (2003) Dasar-dasar Ilmu Politik. Jakarta: Gramedia Pustaka Utama.

Dirdjosanjoto P (2006) Demokrasi dan Potret Lokal Pemilu. Jakarta: Pustaka Pelajar.

DPRD Kabupaten Pati. (2019) Profil Anggota DPRD Periode 2014-2019. Diakses 29 Maret 2019, dari https://dprd.patikab.go.id/page/profil-anggota-dprd-periode-2014-2019/25

Kesbangpol Jateng (n.d.) Diakses 29 Maret 2019, dari https://kesbangpol.jatengprov.go.id

Martin L, Seymour, \& Arbi S (1984) Robert Michels Partai Politik Kecenderungan Oligarkis dalam Birokrasi. Jakarta: CV Rajawali.

Mas'oed M \& MacAndrew C (2006) Perbandingan Sistem Politik. Yogyakarta: Gadjah Mada University Press.

New World Encyclopedia (n.d.) Robert Michels. Diakses 31 Januari 2019, dari https://www.newworldencyclopedia.org/entry/Robert_Michels

Tribunnews (2017) Hasil Rekapitulasi Suara Pilkada Pati, Kotak Kosong Dipilih Lebih dari 170 Ribu Warga. Diakses 26 Januari 2019, dari https://jateng.tribunnews.com/2017/02/23/inihasilrekapitulasi-suara-pilkada-pati-kotakkosong-dipilih-lebih-dari-170-ribu-warga

Tribunnews (2017) Mengejutkan, Ini Alasan Relawan Kotak Kosong Ajukan Gugatan ke MK terkait

Hasil Pilkada Pati. Diakses 26 November 2019, dari https://jateng.tribunnews.com/2017/03/16/mengejutkan-ini-alasan-relawankotakkosongajukan-gugatan-ke-mk-terkait-hasil-pilkada-pati-2017

Varma (2003) Teori Politik Modern. Jakarta: PT Radja Grafindo Persada. 